\begin{tabular}{l|c|c|}
\hline \hline & International Journal of Current Research in \\
\hline & Biosciences and Plant Biology \\
\hline $\begin{array}{l}\text { EXCELLENT } \\
\text { PUBLISHERS }\end{array}$ & Volume 8 - Number o7 (July-2021) • ISSN: $2349-8080$ (Online) \\
\hline
\end{tabular}

\title{
Importance to use nets against pests in fruit-tree protection in Dogbo district in south-western Republic of Benin, West Africa
}

\author{
Nazaire Aïzoun* \\ Laboratory of Pluridisciplinary Researches of Technical Teaching (LaRPET), Normal High School of Technical Teaching \\ (ENSET) of Lokossa, National University of Sciences, Technologies, Engineery and Mathematics (UNSTIM) of Abomey, \\ P. O. Box 133 Lokossa Cell: +22995317939 / +22969465070 Cotonou, Benin
}

*Corresponding author; e-mail: aizoun.nazaire@ yahoo.fr

\begin{tabular}{|c|c|}
\hline Article Info & Abstract \\
\hline $\begin{array}{l}\text { Keywords: } \\
\text { Fruit-tree protection } \\
\text { Mosquito nets } \\
\text { Nets against pests } \\
\text { Olyset net } \\
\text { Permanet } 2.0\end{array}$ & $\begin{array}{l}\text { The current study was aimed to investigate on the use of nets against pests in fruit-tree protection in } \\
\text { couffo department in south-western Republic of Benin, West Africa. The locations of Ayomi, Dévé, } \\
\text { Honton, Lokogohoue, Madjrè and Totchangni were surveyed in June } 2019 \text { to collect information about } \\
\text { the number of fruit-trees protected by nets against pests and those protected by mosquito nets, the kind } \\
\text { of fruit-trees protected and the kind of mosquito nets used. The results showed that one hundred and } \\
\text { twenty five (125) fruit-trees were protected by mosquito nets in Dogbo district whereas only five (05) } \\
\text { fruit-trees were protected by nets against pests. Farmers used different mosquito nets to protect their } \\
\text { fruit-trees such as Permanet } 2.0 \text { and Olyset nets. The use of mosquito nets in fruit-tree protection in } \\
\text { couffo department is a reality in Benin country. For that reason, nets against pests without insecticide } \\
\text { must be promoted to the farmers. These nets are different from mosquito nets distributed free by the } \\
\text { National Malaria Control Program (NMCP). }\end{array}$ \\
\hline
\end{tabular}

- Received: 13 May 2021 • Revised: 12 June 2021 • Accepted: 20 June 2021 • Published Online: 6 July 2021

\section{Introduction}

The range of pests and diseases that can (and do) damage vegetables is immense, but specific ones that have a major influence on productivity in any particular region are usually limited. Pests and diseases may be soil borne or air borne and can be crop specific or generic, so the range of potential control measures is huge. Nevertheless there are a number of basic principles which can be applied to reduce their impact on yield and quality (FAO, 2009).
The use of resistant varieties is an efficient method of reducing pathogen impact on the crop, where suitable varieties are available, as is the use of biological control measures. Such methods tend to be easier to implement in protected cultivation, like greenhouses, but in open field situations can still be effective, economically sound and within smallholders cultural knowledge. Biological control is typically the reduction of pest populations via natural enemies or natural elements and it involves considerable labour activity. Simple examples of biological control are conservation of 
natural enemies, for example lady beetles and lacewings, further the use of such plants as sage, deters the cabbage moth and carrot fly (FAO, 2009).

Pesticides are the most common means currently used to control pests and diseases in vegetables crops. Their use poses several challenges, in terms of safe storage of the pesticide, safe application of the pesticide by the labourer, appropriate frequency of application for optimum benefit, and critically the necessity to ensure that the chemical residue at harvest is well below the critical level. There is also the danger of resistance development to the pesticide by the target pathogen (FAO, 2009).

The agricultural use of insecticides was implicated in the development of resistance to pyrethroids in $A n$. gambiae s.l. populations (Diabaté et al., 2002a). In this study the geographical distribution of resistance was found to decrease in An. gambiae s.l. populations from the Sudanian savannah to sahelian areas, and the highest levels of resistance were found in populations at the sites of cotton cultivation. The areas under cotton cultivation have expanded dramatically in the last 10 years or so, increasing from 210000 ha in 1996 to more than 520000 ha in 2005. A corresponding increase in the level of insecticide use has also been reported, reaching more than $3 \times 10^{6}$ liters of pesticide per cropping campaign (Kaminski, 2007).

Insecticides used in public health against disease vectors are similar to those used for years in agriculture. In Benin Republic, pyrethroids were introduced in agriculture in the $1970 \mathrm{~s}$ and, after 30 years of continuous use, cases of resistance may be found in some populations of insects. With regard to the origins of vector resistance identified in rural and urban areas, various diverging hypothesis are put forward. Some authors incriminate pesticides used in cotton farms and rice fields as the main source of selection of resistance in several species of mosquito in rural environments (Georghiou, 1991 in Central America, Asia and Africa; N'guessan et al., 2003 in Côte d'Ivoire).

In Republic of Benin, study conducted by Akogbeto et al. (2005) reveals that several chemicals are used in the vegetable farms of Houeyiho and Parakou against field pests. These chemicals are mainly pyrethroids, organophosphates and carbamates. These compounds are used as single formulations or as combinations of two or three insecticides of different families, the final aim being to generate a synergy of insecticides for a better pest management. After pesticide treatments in agricultural settings, residues of insecticides get into mosquito breeding sites. These residues have lethal effects on larvae of some populations of mosquito whereas they exert a selective pressure on other populations, leading to a gradual tolerance of insecticide concentrations and to the emergence of resistant populations.

More recently, the emergence of resistance in populations of An. gambiae to common classes of insecticides used in public health has been reported in Republic of Benin (Djogbénou et al., 2008; 2009; Djègbé et al., 2011; Aïzoun et al., 2013a; 2013b; 2013c). Very few researches were published on fruittree protection in Couffo department in south-western Republic of Benin. Therefore, there is a need to carry out new researches for this purpose. The goal of this study was to investigate how farmers used mosquito nets to protect their fruit-trees in Dogbo district in south-western Republic of Benin.

\section{Materials and methods}

\section{Study area}

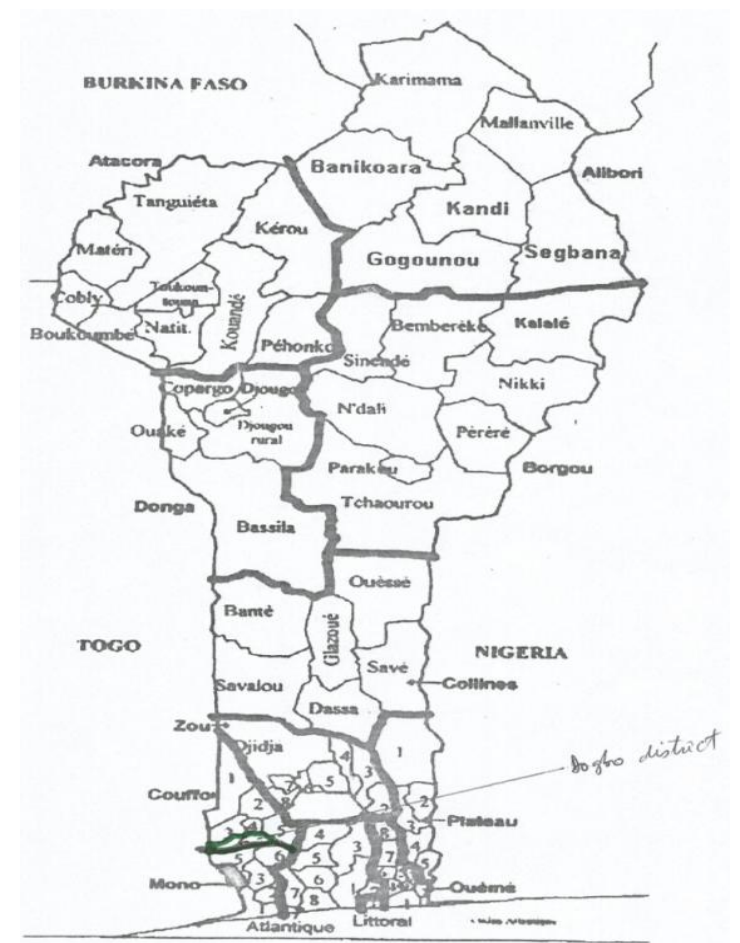

Fig. 1a: Map of Republic of Benin showing Dogbo District. 
The study area is located in Republic of Benin (West Africa) and includes the department of Couffo. Couffo department is located in the south-western Republic of Benin and the study was carried out more precisely in Dogbo district. The southern borders of this district are Lokossa and Bopa districts. The northern border is Djakotomey district. The eastern border is Lalo district and the western border of Dogbo district is Togo republic. Dogbo district covered $475 \mathrm{~km} 2$ and belongs to geographic region of ADJA. The choice of the study site took into account the economic activities of populations, their usual protection practices against mosquito bites and peasant practices to control farming pests. We took these factors into account to appreciate the impact of mosquito nets use in fruit-tree protection in this district. Couffo has a climate with four seasons, two rainy seasons (March to July and August to November) and two dry seasons (November to March and July to August). The temperature ranges from 25 to $30^{\circ} \mathrm{C}$ with the annual mean rainfall between 900 and $1100 \mathrm{~mm}$ (Fig.1a and Fig. 1b).

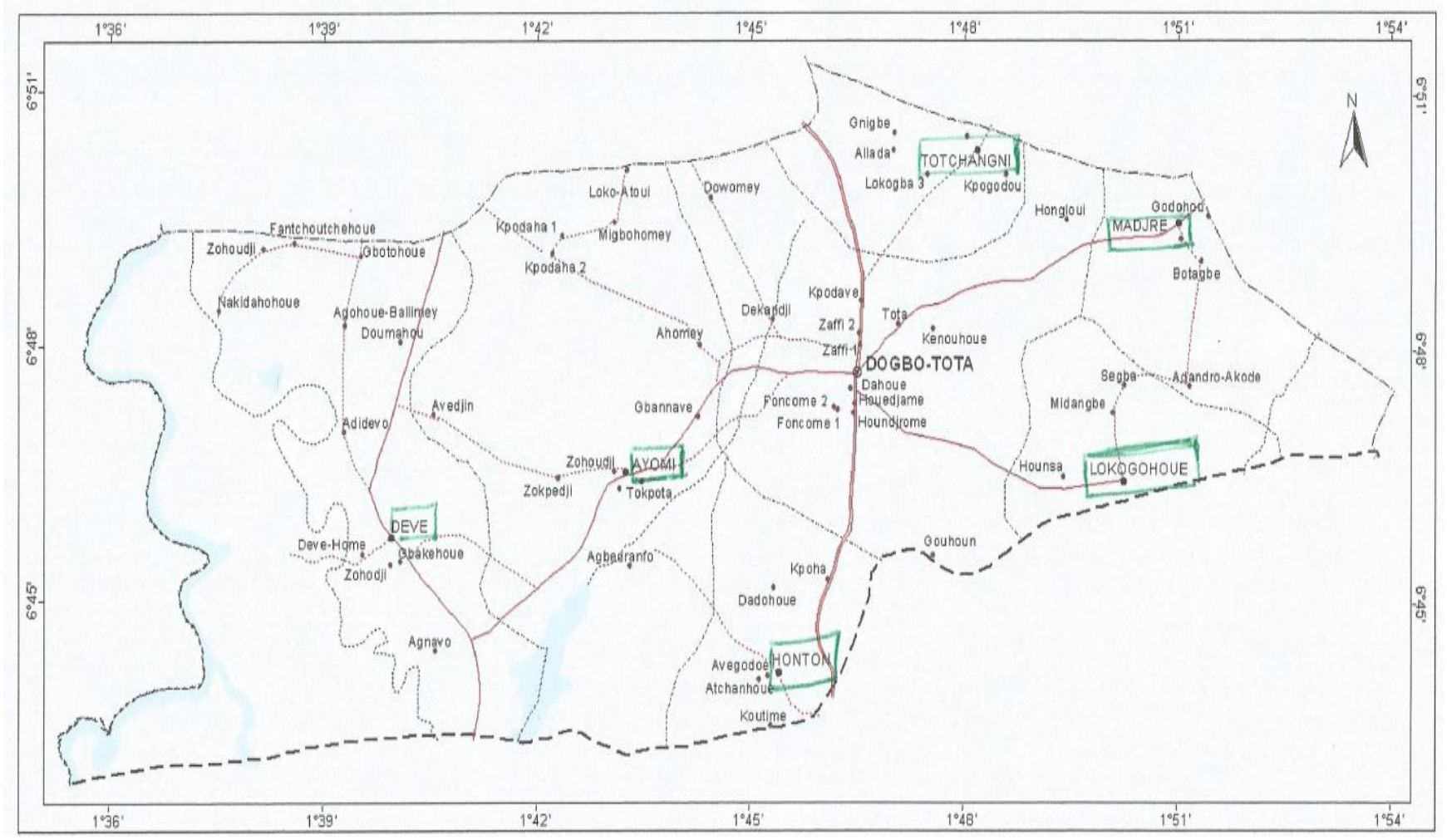

Fig. 1b: Map of Dogbo District showing the study area.

\section{Study design}

The study was carried out in June 2019 during the great rainy season in the locations of Ayomi, Dévé, Honton, Lokogohoué, Madjrè and Totchangni. These locations were surveyed to collect information about the number of fruit-trees protected by nets against pests and those protected by mosquito nets, the kind of fruit-trees protected and the kind of mosquito nets used.

\section{Data analysis}

Analysis using Fisher's exact test and test of proportion was performed on the data sets gathered from the locations surveyed to appreciate how farmers used mosquito nets to protect their trees. The significance level was set at $5 \%$.

\section{Results and discussion}

The analysis of Table 1 showed that one hundred and twenty five (125) fruit-trees were protected by mosquito nets in Dogbo district whereas only five (05) fruit-trees were protected by nets against pests. Thirty two fruittrees were protected by mosquito nets in Totchangni location followed by Dévé location where twenty seven fruit-trees were protected by mosquito nets. Fruit-trees were less protected by mosquito nets in Lokogohoué. 
Table 1. Recording of number of fruit-trees protected by nets against pests and those protected by mosquito nets.

\begin{tabular}{lll}
\hline Locations & $\begin{array}{l}\text { Number of fruit- } \\
\text { trees protected by } \\
\text { nets against pests }\end{array}$ & $\begin{array}{l}\text { Number of fruit- } \\
\text { trees protected by } \\
\text { mosquito nets }\end{array}$ \\
\hline Ayomi & 01 & 15 \\
Dévé & 00 & 27 \\
Honton & 00 & 18 \\
Lokogohoué & 03 & 12 \\
Madjrè & 01 & 21 \\
Totchangni & 00 & 32 \\
\hline
\end{tabular}

The analysis of Table 2 showed that different fruit-trees were protected by mosquito nets in Dogbo district such as: Mango-trees, Banana-trees, Orange-trees, Coconut palms, Papaya trees and Guava-trees [Fig. 2 (a-f)] also shows the different fruit-trees protected by mosquito nets in Dogbo district).

Table 2. Kind of fruit-trees protected by mosquito nets.

\begin{tabular}{ll}
\hline Locations & Kind of fruit-trees protected by nets \\
\hline Ayomi & Mango-tree \\
Dévé & Banana -tree \\
Honton & Orange-tree \\
Lokogohoué & Coconut palm \\
Madjrè & Papaya tree \\
Totchangni & Guava-tree \\
\hline
\end{tabular}

The analysis of Table 3 showed that farmers used different mosquito nets to protect their fruit-trees such as: Permanet 2.0 and Olyset net. Because of emergence of pest resistance to the different pesticides used to protect cultivation in the farms, the peasants or farmers search for alternative methods such as biological control and others.

Table 3. Kind of mosquito nets in fruit-trees protection.

\begin{tabular}{ll}
\hline Locations & Kind of mosquito nets used \\
\hline Ayomi & Permanet 2.0 \\
& Olyset net \\
Dévé & Permanet 2.0 \\
& Olyset net \\
Honton & Permanet 2.0 \\
& Olyset net \\
Lokogohoué & Permanet 2.0 \\
& Olyset net \\
Madjrè & Permanet 2.0 \\
& Olyset net \\
Totchangni & Permanet 2.0 \\
& Olyset net \\
\hline
\end{tabular}

The use of insecticides in households and of pesticides in agricultural settings has been highlighted as a key factor contributing to the emergence of vector resistance. Some authors believe that resistance probably arose from the use of insecticide aerosols in households and some plants used for fumigation over a long period in rural and urban areas. Others believe that the emergence of resistance results from massive use of insecticides against pests in agricultural plantations. Studies conducted by Diabate et al. (2002b) highlight the elevated levels of resistance genes, $k d r$, in $A n$. gambiae collected in cotton-growing areas and constantly subjected to insecticide treatments, as compared to the low frequency of $k d r$ recorded in rural areas where farmers are restricted to food crops for local consumption with no pesticides. In Côte d'Ivoire, the $k d r$ mutation identified in resistant strains of $A n$. gambiae was probably selected as a result of the massive use of DDT and pyrethroids against pests in cotton fields (Chandre et al., 1999; Diabaté, 1999). The hypothesis of a relation between some agricultural practices and the emergence of resistance should not be neglected. In Benin, insecticide treatments against pests in cotton plantations are done twice each month, for an average of three months (between July and October) each year. These treatment periods coincide with the rainy seasons and correspond to the period of high mosquito densities and increased development of Anopheles larvae. In vegetable farms, treatments are more regular and are done throughout the year. Pesticide treatments release active components into the environment of which some get directly into the breeding sites of mosquitoes. There is a high probability that insecticide residues can be found on soil in agricultural areas and could exercise a selection pressure on the larval stage on some populations of mosquitoes.

The obtained results showed that the use of mosquito nets in fruit-tree protection in couffo department is a reality in Benin country. Farmers used different mosquito nets to protect their fruit-trees such as Permanet 2.0 and Olyset net which they received from the different free distribution of Long-Lasting Insecticidal Nets (LLINs) by the National Malaria Control Program (NMCP). Permanet 2.0 and Olyset are impregnated with pyrethroids. According to Zaim et al. (2000), pyrethroids have unique modes of action such as fast knockdown and excito-repellent effects. Some of the mosquito nets used in fruit-tree protection may be bought by farmers or received as donation by them. So, Permanet 2.0 and Olyset net were the nets used by farmers to protect their fruit-trees in Dogbo district. 

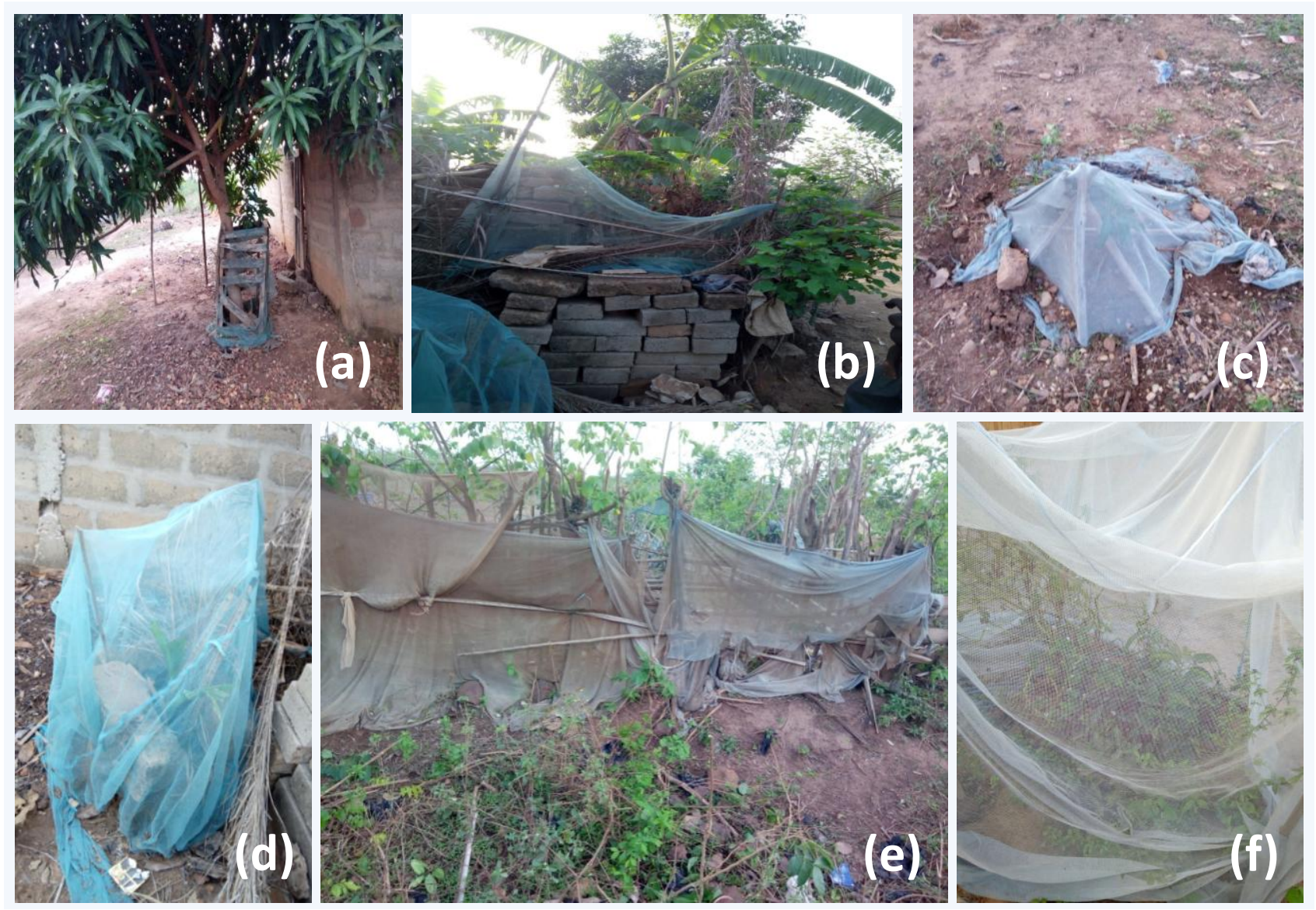

Fig. 2: (a) Mango-tree protected by Olyset net in Ayomi location; (b) Banana-trees protected by Permanet in Dévé location; (c) Orange-tree protected by Permanet in Honton location; (d) Coconut palm protected by Olyset in Lokogohoué location; (e) Papaya-trees protected by Permanets in Madjrè location; (f) Guava-trees (inside of weeds) protected by Permanets in Totchangni location.

These nets were regularly distributed free by the NMCP and they are Long-Lasting Insecticidal Nets (LLINs). Instead of using them against mosquito bites, peasants prefer using them to protect their fruit-trees. In fact, their fruit-trees would be protected. But as the nets were distributed to control malaria vectors, this practice is a threat for NMCP. Therefore, some particular nets without insecticide must be promoted to the farms. These nets are different from mosquito nets distributed free by NMCP and are called nets against pests. The nets against pests respect environment and peasant health by contrast to the use of impregnated mosquito nets or use of pesticides against pests. So, the use of nets against pests is an alternative method to the emergence of pest resistance.

\section{Conclusions}

The farmer practices which use mosquito nets in fruit- tree protection in couffo department would be a threat for malaria control in this region of Benin country even if their cultivations would certainly be protected from farming pests (insects, herbivores and others). Other methods to control farming pests must be vulgarized to them in order to change their behaviors or practices in protected cultivations. These methods won't use mosquito nets or pesticides in order to respect environment and peasant health. One of these methods is the use of nets against pests which is an alternative method to the emergence of pest resistance.

\section{Conflict of interest statement}

Author declares that there is no conflict of interest.

\section{Acknowledgement}

I would like to thank Mister AFFO Johny who had helped me in data collection in Dogbo district. 


\section{References}

Aïzoun, N., Ossè, R., Azondekon, R., Alia, R., Oussou, O., Gnanguenon, V., Aikpon, R., Padonou, G.G., Akogbéto, M., 2013a. Comparison of the standard WHO susceptibility tests and the CDC bottle bioassay for the determination of insecticide susceptibility in malaria vectors and their correlation with biochemical and molecular biology assays in Benin, West Africa. Parasit. Vectors, 6: 147.

Aïzoun, N., Aïkpon, R., Padonou, G.G., Oussou, O., Oké-Agbo, F., Gnanguenon, V., Ossè, R., Akogbéto, M., 2013b. Mixed-function oxidases and esterases associated with permethrin, deltamethrin and bendiocarb resistance in Anopheles gambiae s.l. in the south-north transect Benin, West Africa. Parasit. Vectors, 6: 223.

Aïzoun, N., Aïkpon, R., Gnanguenon, V., Oussou, O., Agossa, F., Padonou, G.G., Akogbéto, M., 2013c. Status of organophosphate and carbamate resistance in Anopheles gambiae sensu lato from the south and north Benin, West Africa. Parasit. Vectors, 6: 274.

Akogbéto, M., Chandre, F., Baldet, T., Diabate, A., Sagnon, N.F., Traoré, S., Etang, J., Boakye, D., 2005. Evolution of pyrethroid resistance in Anopheles gambiae in West Africa. In Final report, WHO/MIM/TDR PI Meeting Addis Abbaba. 14-16 March 2005.

Chandre, F., Darriet, F., Manga, L., Akogbéto, M., Faye, O., Mouchet, J., Guillet, P., 1999. Status of pyrethroid resistance in Anopheles gambiae s.l. Bull. World Health Organ., 77: 230-234.

Diabaté, A., 1999. Evaluation de la résistance des vecteurs du paludisme vis-à-vis des pyréthrinoïdes au Burkina Faso. In Thèse de 3ème cycle Université de Ouagadougou, Faculté de Sciences.

Diabaté, A., Baldet, T., Chandre, F., Akogbeto, M., Darriet, F., Brengues, C., et al., 2002a. The role of agricultural use of insecticides in resistance to pyrethroids in Anopheles gambiae sl in Burkina Faso. Am. J. Trop. Med. Hyg., 67: 617-22.

Diabaté, A., Baldet, T., Chandre, F., Guiguemde, T.R., Guillet, P., Hemingway, J., Hougard, J.M., 2002b.
First report of the $k d r$ mutation in Anopheles gambiae $\mathrm{M}$ form from Burkina Faso, West Africa. Parassitologia, 44: 157-158.

Djègbé, I., Boussari, O., Sidick, A., Martin, T., Ranson, H., Candre, F., Akogbéto, M., Corbel, V., 2011. Dynamics of insecticide resistance in malaria vectors in Benin: first evidence of the presence of L1014S $k d r$ mutation in Anopheles gambiae from West Africa. Malar. J., 10: 261.

Djogbenou, L., Dabire, R., Diabate, A., Kengne, P., Akogbeto, M., Hougard, J.M., Chandre, F., 2008. Identification and geographic distribution of the ACE-1R mutation in the malaria vector Anopheles gambiae in south-western Burkina Faso, West Africa. Am. J. Trop. Med. Hyg., 78: 298-302.

Djogbenou, L., Pasteur, N., Akogbeto, M., Weill, M., Chandre, F., 2009. Insecticide resistance in the Anopheles gambiae complex in Benin: a nationwide survey. Med. Vet. Entomol., 69: 160-164.

FAO, 2009. Growing vegetables for home and market, by Mike Nichols and Martin Hilmi, Rural Rural Infrastructure and Agro-Industries-Division Food and Agriculture Organization of the United Nations, Diversification booklet number 11, Rome 2009.

Georghiou, G.P., Lagunes-Tejada, A., 1991. Cases of resistance in Insecta. The Occurrence of resistance to pesticides in arthropods. Food and Agriculture Organisation of the United Nations: Rome.

Kaminski, J., 2007. Reforme de la filière cotonnière burkinabé - Retour sur dix ans de mutations: Analyse des impacts économiques et sociaux sur les producteurs et implications des organisations agricoles. Toulouse: Rapport Université de Toulouse.

N'guessan, R., Darriet, F., Guillet, P., Carnevale, P., Traoré-Lamizana, M., Corbel, V., Koffi, A.A., Chandre, F., 2003. Resistance to carbosulfan in field populations of Anopheles gambiae from Côte d'Ivoire based on reduced sensitivity of acetylcholinesterase. Med. Vet. Entomol., 17: 19-25.

Zaim, M., Aitio, A., Nakashima, N., 2000. Safety of pyrethroid-treated mosquito nets. Med. Vet. Entomol., 14: 1-5.

\section{How to cite this article:}

Aïzoun, N., 2021. Importance to use nets against pests in fruit-tree protection in Dogbo district in south-western Republic of Benin, West Africa. Int. J. Curr. Res. Biosci. Plant Biol., 8(7): 17-22.

doi: https://doi.org/10.20546/ijcrbp.2021.807.003 